\title{
Human capital development: development of professional competencies through soft skills
}

\section{Desenvolvimento do capital humano: desenvolvimento de competências profissionais por meio de soft skills}

\section{Desarrollo de capital humano: desarrollo de competencias profesionales a través de habilidades blandas}

\author{
Valeriia Valerevna Semenova1 ${ }^{1}$, Alexander Nikolaevich Zelenyuk ${ }^{2}$ iD, \\ Yuri Anatolyevich Savinov ${ }^{3}$ iD
}

\footnotetext{
${ }^{1}$ Moscow Polytechnic University, Moscow, Russian.

${ }^{2}$ Moscow State Institute (University) of International Relations of the Ministry of Foreign Affairs of Russia, Moscow, Russian Federation.

${ }^{3}$ Russian Foreign Trade Academy, Moscow, Russian Federation.

Corresponding author:

Valeriia Valerevna Semenova

Email: semenova.valeriia.v@yandex.ru
}

How to cite: Semenova, V. S., Zelenyuk, A. N., \& Savinov, Y. A. (2021). Human capital development: development of professional competencies through soft skills. Revista Tempos e Espaços em Educação, 14(33), e15253.

http://dx.doi.org/10.20952/revtee.v14i33.15253

\begin{abstract}
The goal of the article is to analyze the development of the professional competency of leadership through the development of soft skills in the students of Russian engineering universities on the example of the Moscow Polytechnic University. The most demanded and dynamic part of the labor market is currently represented by engineering specialists. However, successful professional and career growth, as well as the effective development of human capital as the main resource of the innovative development of modern society, requires a combination of engineering (hard skills) and humanitarian (soft skills) abilities in a specialist. The development of many socially significant processes in modern society demonstrates aggravated contradictions and the development of new realization trends many of which are associated with changes in the parameters of these processes which, in turn, is determined by the mass implementation of innovative digital technologies and globalization processes. Globalization as a process ensuring the accessibility and openness of information has a significant impact on the transformation of national values within a country in favor of the emergence of global social, moral, and legal values and social behavior norms in the field of political and state power, as well as the economy. Leadership as a social phenomenon bearing the main load of managing all socially significant processes is also changing. Leadership as a social phenomenon is subject to constant scientific study and analysis. For this purpose, the GLOBE
\end{abstract}


(Global Leadership and Organization Behavior Effectiveness) International Research Program was created. The GLOBE program coordinates the study of leadership in more than 60 countries which also supports the relevance of researching the phenomenon of leadership. In the professional activity, leadership manifests through the "leadership qualities" competency.

Keywords: Innovations. Soft skills. Human capital. Professional competence. Skills.

\section{RESUMO}

O objetivo do artigo é analisar o desenvolvimento da competência profissional de liderança por meio do desenvolvimento de soft skills em estudantes de universidades russas de engenharia a exemplo da Universidade Politécnica de Moscou. A parte mais exigida e dinâmica do mercado de trabalho é atualmente representada por especialistas em engenharia. No entanto, o crescimento profissional e de carreira de sucesso, bem como o desenvolvimento eficaz do capital humano como principal recurso do desenvolvimento inovador da sociedade moderna, requer uma combinação de habilidades de engenharia (hard skills) e humanitárias (soft skills) em um especialista. 0 desenvolvimento de muitos processos socialmente significativos na sociedade moderna demonstra contradições agravadas e o desenvolvimento de novas tendências de realização, muitas das quais estão associadas a mudanças nos parâmetros desses processos que, por sua vez, são determinados pela implementação em massa de tecnologias digitais inovadoras e da globalização processos. A globalização como um processo que garante a acessibilidade e abertura da informação tem um impacto significativo na transformação dos valores nacionais dentro de um país em favor do surgimento de valores sociais, morais e legais globais e normas de comportamento social no campo do poder político e estatal, bem como a economia. A liderança como fenômeno social que carrega a principal carga de gerenciamento de todos os processos socialmente significativos também está mudando. A liderança como fenômeno social está sujeita a constantes estudos e análises científicas. Para tanto, foi criado o Programa Internacional de Pesquisa GLOBE (Liderança Global e Eficácia do Comportamento Organizacional). O programa GLOBE coordena o estudo da liderança em mais de 60 países, o que também sustenta a relevância de pesquisar o fenômeno da liderança. Na atividade profissional, a liderança se manifesta por meio da competência "qualidades de liderança".

Palavras-chave: Inovações. Habilidades interpessoais. Capital humano. Competência profissional. Habilidades.

\section{RESUMEN}

El objetivo del artículo es analizar el desarrollo de la competencia profesional de liderazgo a través del desarrollo de habilidades blandas en los estudiantes de las universidades de ingeniería rusas en el ejemplo de la Universidad Politécnica de Moscú. La parte más demandada y dinámica del mercado laboral está representada actualmente por ingenieros especialistas. Sin embargo, el crecimiento profesional y profesional exitoso, así como el desarrollo efectivo del capital humano como principal recurso del desarrollo innovador de la sociedad moderna, requiere una combinación de habilidades de ingeniería (habilidades duras) y humanitarias (habilidades blandas) en un especialista. El desarrollo de muchos procesos socialmente significativos en la sociedad moderna demuestra contradicciones agravadas y el desarrollo de nuevas tendencias de realización, muchas de las cuales están asociadas con cambios en los parámetros de estos procesos que, a su vez, están determinados por la implementación masiva de tecnologías digitales innovadoras y la globalización. procesos. La globalización como proceso que asegura la accesibilidad y apertura de la información tiene un impacto significativo en la transformación de los valores nacionales dentro de un país a favor del surgimiento de valores sociales, morales y legales globales y normas de comportamiento social en el campo del poder político y estatal. , así como la economía. El liderazgo como fenómeno social que soporta la carga principal de gestionar todos los procesos socialmente significativos también está cambiando. El liderazgo como fenómeno social está sujeto a constantes estudios y 
análisis científicos. Para ello, se creó el Programa Internacional de Investigación GLOBE (Global Leadership and Organization Behavior Effectiveness). El programa GLOBE coordina el estudio del liderazgo en más de 60 países, lo que también respalda la relevancia de investigar el fenómeno del liderazgo. En la actividad profesional, el liderazgo se manifiesta a través de la competencia "cualidades de liderazgo".

Palabras clave: Innovaciones. Habilidades blandas. Capital humano. Competencia profesional. Habilidades.

\section{INTRODUCTION}

The importance of human capital for the development of socio-economic processes in modern society is growing rapidly since said development is associated with the possibilities of innovative strategic solutions to global problems facing humanity, such as the depletion and uneven distribution of resources, competition wars, the development of substitutional and green technologies, climate change, etc. Innovations and digital technologies require special professional competencies from highly demanded workers who occupy a key position in the labor market. Such workers determine the level of innovative development of an organization and ultimately the competitiveness of the country as a whole (Sekerin et al., 2018; Gorokhova et al., 2018).

The concept "human capital" was introduced into science in 1961 by Theodore Schultz (1961). Schultz defined human capital as the complex of workers' knowledge and skills presenting economic value and contributing to labor productivity growth. An undoubted contribution to the development of the theory of human capital and the study of its role in the economy was made by Gary Becker who proved the importance of education and training as the main components contributing to the growth and development of human capital. Becker was one of the first to propose a model for the economic assessment of investment in human capital. According to Becker, investment in human capital involves education, accumulation of professional experience, etc. (Becker, 1994). The modern model for the assessment of the impact of education quality on the formation and development of human capital is presented in the WEF Global Human Capital Index (WEF: The Global Human Capital Report, 2017). In WEF, however, only the skills that develop over time and are not an innate given are classified as human capital. The overall index comprises four groups of sub-indexes characterizing the level of human capital development, mastery over the following competencies: 1 - Capacity; 2 - Deployment; 3 -Development; 4 - Know-How (WEF: The Future of Jobs Report, 2018). J.W. Pellegrino and M.L. Hilton proposed to divide the demanded competencies of the 21st century into three clusters:

1. cognitive - this group of competencies includes digital and research skills, as well as critical thinking;

2. interpersonal - this group involves competencies necessary for interpersonal interaction, specifically teamwork and leadership skills;

3. personal - this group presents competencies ensuring self-organization and selfdevelopment such as self-control, self-evaluation, and intellectual openness (Pellegrino \& Hilton, 2012).

The opinion of many Russian experts on the 2025 competency model also converges on identifying three main clusters: cognitive, socio-behavioral, and digital. Thus, it can be concluded that both Russian and global experts in the sphere of competencies and human capital development identify leadership as one of the key competencies of the future. Leadership also presents a resource since the development of leadership qualities conditions the development of competencies of the cognitive and digital clusters.

Modern Russian higher education pays great attention to the problem of the development of human capital through the competency approach for the improvement of young specialists' competitiveness in the labor market on which the development of innovative digital technologies 
and the economy depends (Semenova et al., 2019; Pershina et al., 2019; Sikyr et al., 2018). The Moscow Polytechnic University was one of the first to introduce project activity in the education process to form a balance of competencies of all major clusters, as well as to compensate for the "imbalances" of classical engineering education towards the development of digital and cognitive competencies and to lay the foundations for the development of social and behavioral competencies, the key one of them being leadership.

\section{METHODOLOGY}

The present study was conducted on students of the Moscow Polytechnic University as a part of them mastering the "Project activity" discipline. The study deploys classical scientific methods used in psychology, economics, and sociology - the observation method and the method of analyzing the results of observation to identify specific behavioral and individual characteristics. The object of observation and analysis is presented by social behavior and the elements (patterns) of social interpersonal interaction in the process of team building, nominating a team leader, entering the leadership role, and the leader's interaction with the team. The process of team building comprised three consecutive stages:

Stage 1: Initial acquaintance, self-nomination as a team leader, and the formation of teams;

Stage 2: Entering the role of a team leader, the formation of the main principles of social interaction within the team, and teamwork organization and control;

Stage 3: Completion of the work of the team, work results presentation.

The study aimed to identify the behavioral patterns necessary for the development of various leadership qualities in first-year students at the start of their education, as well as to analyze the formation of behavioral patterns characteristic for the development of leadership qualities after training in teamwork and group interaction within the framework of mastering the "Project activity" discipline. The evaluation of behavior patterns was conducted following the assessment technology; the scale of assessment and development of the "leadership skills" competency used in the study is presented in Table 1. The assessment was carried out by the curators of the project activities.

Leadership skills include a high degree of influence on others, the ability to lead a team, to gain authority (competency 1 - influence); the ability to change people's behavior and motivate them to achieve a result (competency 2 - motivation); the ability to make managerial decisions and take responsibility for them (competency 3 - organization and decision making).

Table 1. The "leadership skills" competency.

\begin{tabular}{|c|c|}
\hline 3 & in addition to level 2: \\
\hline $\begin{array}{l}\text { High (advanced) level of } \\
\text { COMPETENCY DEVELOPMENT }\end{array}$ & $\begin{array}{l}\text { Takes initiative and speaks on behalf of the team. Has influence over the } \\
\text { team. Often is the author of project solutions and ideas during the project } \\
\text { realization. Actively takes responsibility for managerial decisions. Works on } \\
\text { team building. Skillfully argues and defends their viewpoint. }\end{array}$ \\
\hline $\begin{array}{l}2 \\
\text { Baseline level of COMPETENCY } \\
\text { DEVELOPMENT }\end{array}$ & $\begin{array}{l}\text { Can influence others, can unite and lead a team, and gain authority. Can } \\
\text { change people's behavior and motivate them to achieve a result. Is ready to } \\
\text { make managerial decisions and take responsibility for them. Provides new } \\
\text { ideas during problem-solving. Can argue their viewpoint when facing critical } \\
\text { remarks from colleagues. Skillfully uses the signs of formal status to create } \\
\text { psychological distance when necessary. }\end{array}$ \\
\hline
\end{tabular}




\section{1}

INSUFFICIENT DEVELOPMENT OF THE COMPETENCY

0

THE COMPETENCY IS NOT DEVELOPED
Can head the team to solve a specific task. Communicates with the subordinates formally, or on the contrary, too familiarly, without any distance, but can show initiative (occasionally). Tends to avoid responsibility when making difficult managerial decisions. Retreats from their position once faced with objections from colleagues.

Experiences difficulties leading the team or taking initiative. Does not attract attention and is not respected by team members (colleagues). Often presents a cover for an informal leader who actually leads the team. Keeps themself apart in the team or tries to not stand out too much and be "like everyone else". Does not take initiative and responsibility for the decisions made.

Stage 1. Students were asked to voluntarily nominate themselves as a leader of a potential team. To do so, the potential leader had to prepare a self-presentation speech. Requirements and limitations for the self-presentation were identical for all potential leaders. The self-presentation had to reflect the main principles of teamwork and interpersonal interaction the potential leader was going to use for the formation and preservation of team spirit and unity; the nominee also had to describe their strong personal qualities and attractiveness as a leader. Out of 68 study participants, eight people volunteered to test their abilities as a leader and three of them did not succeed in assembling a team. At the first stage, the "leadership skills" competency was assessed through the observation and analysis of the speech and the initial interaction with team members. The results of the analysis are presented in figure 1.

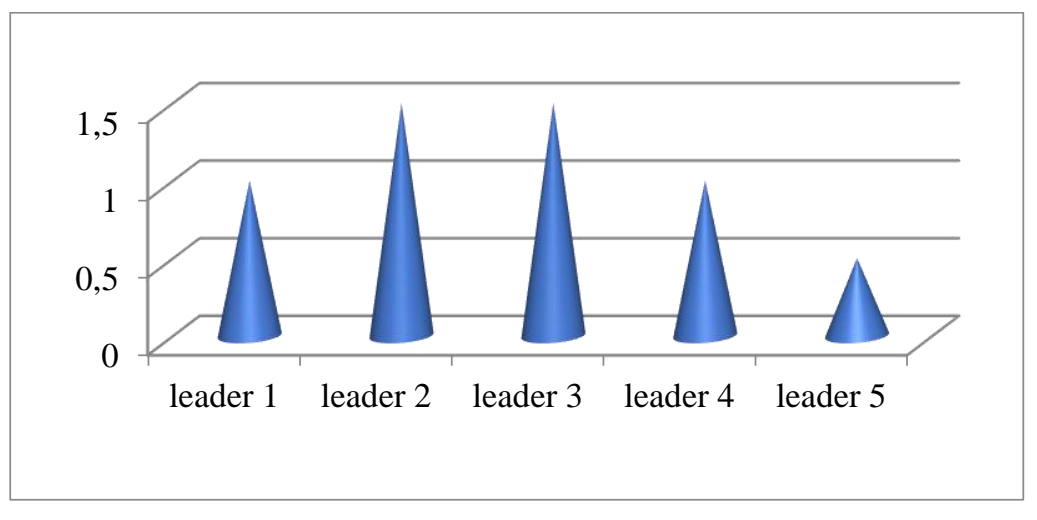

Figure 1 illustrates that leader 2 and leader 3 are more predisposed to the development of leadership qualities compared to leaders 1, 4, and 5. Since the "leadership qualities" competency can be divided into sub-competencies of "influence" (competency 1), "motivation" (competency 2), and "organization and decision making" (competency 3), we conducted additional analysis of these competencies in the leaders' behavior. The results of the said analysis are presented in Figure 2.

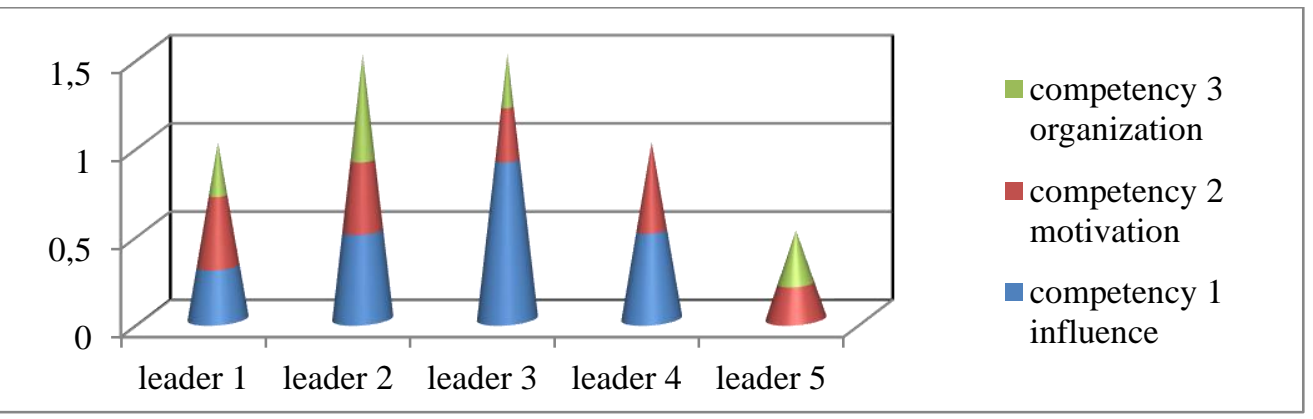


Stage 2. At the second stage, the leaders had to create the basis of team culture, distribute team roles, determine the goals and objectives of teamwork, and determine the foundations of motivation for teamwork to be aimed at achieving these goals and results. The teams were provided with the same creative task (project) and each team had to develop and present a creative solution at the third stage. Leader 5 did not cope with the tasks of the second stage and their team elected a new leader. It should be noted here that when the competencies of leader 5 were assessed at the first stage, the development of the "influence" competency was at a zero level (Figure 2). The results of the development of the "leadership skills" competency after the second stage of the study are presented in figure 2.

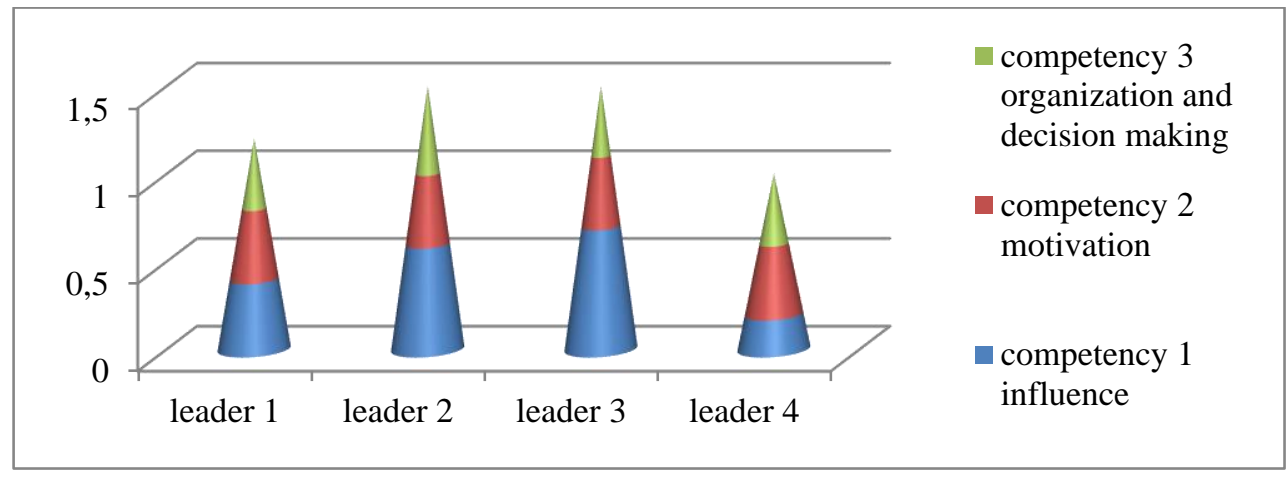

The analysis of the assessment of the leadership competency after the second stage of the study demonstrates that the studied competency developed in leader 1 and leader 4. Comparative analysis of the "influence", "motivation", and "organization and decision making" competencies after the second stage also shows some changes. For instance, leader 4 started to develop the "influence" competence which they lacked at the first stage. The ratio of the "influence", "motivation", and "organization" competencies in the structure of the leadership competency changed in leader 3: a reduction in the "influence" competency led to the development of the "organization and decision making" competency.

Stage 3. At the third stage, the teams had to present the result of their teamwork the quality of which was then evaluated by a group of experts (curators, teachers) along with the creativity of the solution. The leadership competency was also assessed after the teamwork was finished and the conclusions were drawn. The results of this round of assessment are presented in figure 3 .

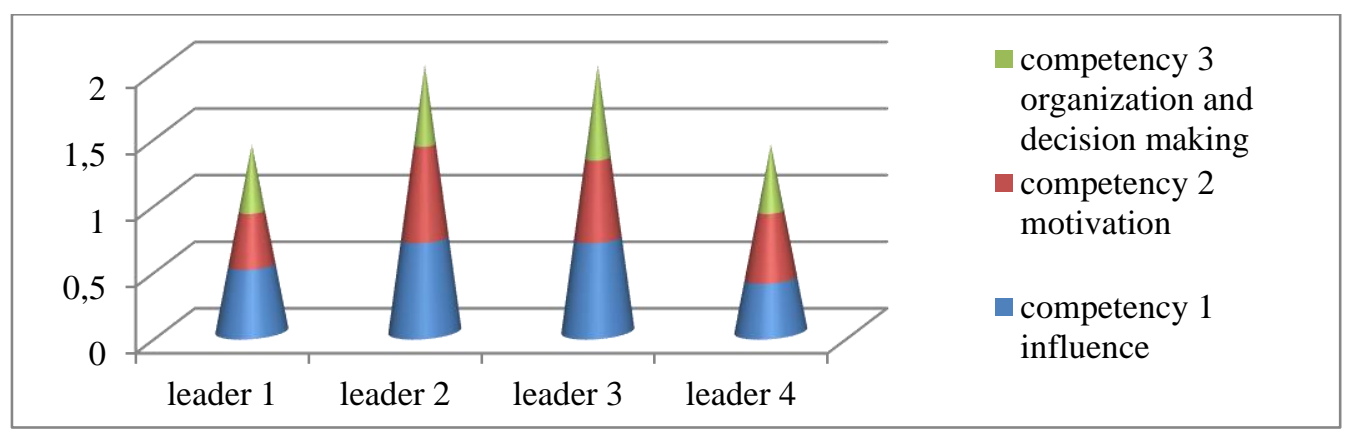

The analysis shows that the "leadership qualities" competency improved in all leaders as a result of its practical use in teamwork. The best result of teamwork was achieved by the team of leader 3 who initially demonstrated high development of the "leadership qualities" competency and its components and improved both the "leadership qualities" competency and its components in the course of the experiment. Leader 1 and leader 4 who had a lower level of development of the leadership competency at the first stage also demonstrate the development of leadership skills, as well as a changed ratio of sub-competencies within the "leadership skills" competency. 


\section{RESULTS}

According to studies and surveys of employers, a young specialist has to have a wide range of interdisciplinary knowledge and competencies which determines the implementation of the interdisciplinary approach in the educational process at the Moscow Polytechnic University where the "Project activity" discipline is taught. Moreover, the development of labor market globalization processes and the opportunities for professional and labor mobility which are now becoming a reality implies the demand for soft skills which include leadership. Leadership skills determine the development of many professional competencies which contribute to a more targeted development of competencies of other clusters, as well as to obtaining interdisciplinary knowledge and skills highly demanded in the 21st century (Goleman, 2016; Maxwell, 2006; Charysheva, 2014). Leadership is a natural social and psychological process based on the effect of the influence of a leader's authority on group members. The study results support the idea that the "influence" competency presents one of the key competencies of a leader and can serve as a basis for further development. The development of leadership skills is accompanied by the development of soft skills in all team members since a collective result needs to be achieved (Pellegrino \& Hilton, 2012). The WEF Global Human Capital Index includes a sub-index of Capacity determining the value of formal education (WEF: The Global Human Capital Report, 2017). A high level of formal education guarantees quick adaptation to new technologies and innovations as a basis of competitiveness. This fact allows us to speak about not only the development of human capital but also about the development of social intellect as a quality demanded by employers and affecting the competitiveness of a young specialist (Butenko et al., 2017). Social intellect presenting the skills of effective social interaction, creating, developing, and maintaining productive social contacts, and maintaining trusting relationships with colleagues is highly important for a specialist's competitiveness. The term "social intellect" was introduced into science by Edward Thorndike who defined it as an ability to understand other people regardless of their sex and gender, as well as to manage relationships with them. A skill viewed as a major component of social effectiveness by employers is behavioral effectiveness. Behavioral effectiveness implies the ability to build relationships with counterparties in specific situations and "inspire others to be effective" and can serve as a basis for leadership (Butenko et al., 2017; Semenova \& Koshel, 2017).

\section{DISCUSSION}

Leadership as a social phenomenon and a demanded professional competency included in soft skills and affecting the development of human capital draws increased interest of researchers and employers alike (Harvard Business Review, 2011; Abuziarova et al., 2019; Dyakonov et al., 2019). The development of competencies that are demanded in all spheres of activity and are, therefore, universal is a key to innovative development and competitiveness since they ensure and increase openness to new experiences which determines the potential for professional and personal development. The relevant issues that remain unanswered or ambiguous include the following:

- although the WEF only classifies the skills that develop over time and are not an innate given as human capital (WEF: The Future of Jobs Report, 2018), such an approach raises some doubts since the development of some competencies is associated with the development of innate inclinations;

- the development of digital technologies makes classical education insufficient for competitiveness in the labor market and unable to guarantee the demand for a young specialist;

- one of the main requirements posed to skills and competencies is flexibility. Flexibility implies the ability to transform (adapt) a skill from one sphere for a different sphere which can be ensured by interdisciplinary knowledge which promotes the development of the ability to combine 
the elements of knowledge from different areas which results in innovation (Willison \& O'Regan, 2007; 2015);

- the development of human capital is contingent on education and training determining the development of competencies and skills and forming the basis for innovation and competitiveness;

- the development of soft skills (including leadership) as a result of interdisciplinary knowledge and the ability to adapt to the conditions of the global labor market presents a factor in the improvement of human capital competitiveness;

- the development of leadership as one of the most demanded soft skills, a component of social intellect, and a social and psychological phenomenon presents a crucial element in the set of competencies of a young specialist from the employer's viewpoint.

\section{CONCLUSION}

Dynamic digitalization processes rapidly change the labor market and, therefore, the requirements of employers for the professional competencies of a specialist towards their greater universality and flexibility. These characteristics are demonstrated by soft skills which, in turn, leads to changes in the requirements for education. In engineering education, the development of soft skills in general and the leadership competency, in particular, improves the demand for specialists due to their more effective adaptation to the changing conditions of the labor market and mobility of the acquired professional competencies.

Since some of the key competencies included in the soft skills group can be divided into components as was illustrated in the example of the "leadership skills" competency, the effective development of the leading competency determines a positive dynamic in the development of other components and the development of component competencies not only affects the dynamic of the key competency development but also changes the ratio of components depending on how demanded they are in the present situation. The present study confirms this statement. Moreover, the component competencies can belong not only to competencies of the same cluster but also to competencies from different clusters which improves the development of professional competence as a whole and positively affect the development of human capital.

Authors' Contributions: Paste the contributions of each author. Each author must have made at least one of the following contributions to the completion of the manuscript: 1) conception and design, 2) acquisition of data, 3) analysis and interpretation of data, 4) drafting the article, 5) critical review of important intellectual content. In addition, all authors must have made the following contribution: 6) final approval of the version to be published (at the end of this topic, keep the following: "All authors have read and approved the final version of the manuscript").

Ethics Approval: Approved by Human Research Ethics Committee of Federal University of Sergipe. CAAE: 00000000.0.0000.0000. If there are no ethics approval, keep the following: "Not applicable".

Acknowledgments: Paste the acknowledgments. If there are no acknowledgments, keep the following: "Not applicable".

\section{REFERENCES}

Abuziarova, D., Belousova, V., Kraiushkina, Zh., Lonshchikova, lu., Nikiforova, E., Chichkanov, N. (2019). Rol chelovecheskogo kapitala $v$ sfere nauki, tekhnologii i innovatsii. [The role of human capital in the sphere of science, technology, and innovation]. FORSAIT, 13(2).

Araujo, A., \& Silva, I. P. (2020). Maker culture and educational robotics in physics teaching: developing an automated traffic light in high school. Journal of Research and Knowledge Spreading, 1(1), e11654.

Becker, G.S. (1994). Human capital: A theoretical and empirical analysis, with special reference to education. Chicago: The University of Chicago Press.

Butenko, V., Polunin, K., Kotov, I., Sycheva, E., Stepanenko, A., Zanina, E., Lomp, S., Rudenko, V. (2017). Rossiia 2025 ot znanii k talantam. [Russia 2025 - from knowledge to talents]. Moscow: The Boston Consulting Group. 
Charysheva, S.R. (2014). Liderstvo i mentalnost [Leadership and mentality]. Molodoi uchenyi, 20 (79), 667-671.

Dyakonov, M.Y., Novikov, A.V., Slabkaya, D.N., Balova, S.L., Sekerin, V.D., Gorokhova, A.E. (2019). Customer service quality management system. International Journal of Innovative Technology and Exploring Engineering, 8(10), 2474 2478.

Goleman, D. (2016). Liderstvo (Luchshie stati ot Harward Business Review) [Leadership (Best articles from Harward Business Review)]. Moscow: Alpina Pablisher.

Gorokhova, A.E., Gaisina, L.M., Gareev, E.S., Shutov, N.V., Shakirova, E.V. (2018). Application of Coaching Methods at Agricultural and Industrial Enterprises to improve the Quality of Young Specialists' Adaptation. Quality-Access to Success, 19(164), 103-108.

Harvard Business Review. (2011). Kreativnoe myshlenie v biznese [Creative thinking in business]. Washington: United Press.

Maxwell, J. (2006). Lider na 360 gradusov [The 360 Degree Leader.]. Minsk: Poppuri.

Oliveira, A. M., Gerevini, A. M., \& Strohschoen, A. A. G. (2017). Diário de bordo: uma ferramenta metodológica para o desenvolvimento da alfabetização científica. Revista Tempos e Espaços em Educação, 10(22), 119-132.

Pellegrino, J.W., Hilton, M.L. (2012). Education for life and work: Developing transferable knowledge and skills in the 21st Century. Washington: National Academy of Sciences.

Pershina, K.V., Gorokhova, A.E., Popovskii, lu.N., Sekerin, V.D., Tarabrin, Ph.M. (2109). Development of manufacturing systems based on integration with controlling as a competitive advantage of industrial companies. International Journal of Innovative Technology and Exploring Engineering (IJITEE), 8 (6), 610-612

Rodrigues, B. M., Santos, J. E. B., \& Vasconcelos, C. A. (2020). Conceptions of undergraduate students in Chemistry on the use of interactive interfaces in and for the activities developed in the distance course. Journal of Research and Knowledge Spreading, 1(1), e11649.

Santos, J. E. B. (2020). Cartographic narratives: the teaching of mathematics and ICT. Journal of Research and Knowledge Spreading, 1(1), e11645.

Schultz, T.W. (1961). Investment in human capital. The American Economic Review, 51(1), 1-17.

Sekerin, V.D., Gaisina, L.M., Shutov, N.V., Abdrakhmanov, N.Kh., Valitova, N.E. (2018). Improving the quality of competence-oriented training of personnel at industrial enterprises. Quality - Access to Success, 19(165), 68-73.

Semenova, V.V, Sekerin, V.D. , Efremov. A.A. (2019). Aktualnost strategii formirovaniia innovatsionnogo znaniia dlia razvitiia vysshei shkoly $v$ usloviiakh globalizatsii. [Relevance of the innovative knowledge formation strategy for the development of higher education in the context of globalization] In book: Rossiia - Belarus: 20 let Soiuznomu gosudarstvu (obrazovatelnye, nauchno-issledovatelskie i sotsiogumanitarnye aspekty razvitiia rossiisko-belorusskikh otnoshenii). Materialy Mezhdunarodnoi nauchno-prakticheskoi konferentsii.

Semenova, V.V., Koshel, I.S. (2017). Upravlenie znaniiami: formirovanie professionalnykh kompetentsii. [Managing knowledge: the formation of professional competencies]. Ekonomika i predprinimatelstvo, 9, 3.

Sikyr, M., Abrashkin, M.S., Sekerin, V.D., Gorokhova, A.E. (2018). The impact of R\&D of high-tech engineering on GDP growth in Russia. International Journal of Mechanical Engineering and Technology, 9, 248-263.

WEF: The Future of Jobs Report. (2018). Cologni: World Economic Forum.

WEF: The Global Human Capital Report. Preparing People for the Future of Work. (2017). Cologni: World Economic Forum.

Willison, J., O’Regan, K. (2007). Commonly known, commonly not known, totally unknown: A framework for students becoming researchers. Higher Education Research \& Development, 26(4), 393-409.

Willison, J., O’Regan, K. (2015). Researcher skill development framework. Adelaide: University of Adelaide. Retrieved from: https://www.adelaide.edu.au/rsd/framework/rsd7/

Received: 11 January 2021 | Accepted: 3 February 2021 | Published: 16 February 2021

This is an Open Access article distributed under the terms of the Creative Commons Attribution License, which permits unrestricted use, distribution, and reproduction in any medium, provided the original work is properly cited. 